\title{
FEMINIST TRANSNATIONAL DIASPORA IN THE MAKING. THE CASE OF THE \#BLACKPROTEST
}

\author{
GRETA GOBER, JUSTYNA STRUZIK
}

\begin{abstract}
This paper discusses the \#BlackProtest mobilization among Polish migrant women living in four European cities. The \#BlackProtest is the name of the most impressive women's rights protest in Poland's recent history. The main research question explored in this small study was what the act of solidarity, demonstrated in organizing the \#BlackProtest internationally, meant for its organizers. The analysis of the reasons behind the transnational \#BlackProtest organizing revealed that it is insufficient to talk about \#BlackProtest mobilization only in terms of transnational activism. The theoretical framework of the study needed to be expanded from social movements to contemporary diasporas and the discussion demonstrated how through a process of identities, heterogeneity and boundaries' negotiations a feminist diaspora was formed. Social movements' theories, explaining the role of connective leadership, discursive opportunity structures and emotions in social mobilization helped to demonstrate how this media-driven mobilization initiated the emergence of a transnational, feminist diaspora.
\end{abstract}

Keywords: transnational diaspora, feminist mobilization, media-driven mobilization, \#BlackProtest 
The \#BlackProtest is the name of the most impressive women's rights protest in Poland's recent history. The protest earned its name from its participants, who wore black clothes to symbolically refer to death and mourning for lost reproductive rights. The mobilization, in the form of a general national walkout, demonstrations, marches, petitions and pickets, was organized under the hashtag and name Czarny Protest (Black Protest) and lasted, it its most intensive form, for approximately six months, starting from 23 September 2016. On that day the majority government formed by the Law \& Justice party approved a decision that made the possibility of a total ban on abortion rights in Poland very realistic. This attempt to introduce a total ban on abortion rights was spearheaded by an ultra-conservative NGO - Fundacja Proprawo do życia (Pro Foundation - the right to live) and their civil initiative called Stop Aborcji (Stop Abortion), supported by Institute Ordo Iuris, a very influential, conservative anti-choice legal think-thank that called for an absolute prohibition of abortion and for criminal liability for anyone who "causes the death of a conceived child". Under the human embryo protection rhetoric, the proposed legal solutions, if approved, threatened not only abortion rights, but also prenatal care, in-vitro fertilization procedures and even post-colloid contraception or the socalled "morning after" pill (Gober 2016a, 2016b). The government approved the Stop Abortion initiative for further proceedings by the Justice and Human Rights Committee while simultaneously rejected a counter civil-initiative Ratujmy Kobiety (Save the Women), which was also brought to the Parliament and advocated for liberalization of the existing abortion law. The combination of these decisions started a women-led civic uprising that spread throughout the country and abroad and reached its peak on Monday, 3 October 2016. On October 6th, the Parliament voted to reject the Stop Abortion bill. That Monday became \#Black Monday and was declared a victory by the movement but the mobilization did not end there. The \#BlackMonday was followed by a \#BlackFriday and many other initiatives, all organized in response to the Polish government's new plans and decisions regarding limiting or interfering with women's reproductive rights and health. Each mobilization in Poland was accompanied by solidarity mobilizations organized by mostly Polish migrant women across the world under the hashtag \#SolidarityWithPolishWomen. For example, the \#BlackMonday mobilized approximately 150 thousand people (Gober 2016 a, b), gathered around over 200 events in Poland (pickets, demonstrations, marches), and over 49 solidarity events organized mostly in Europe, but also in USA, Canada, Australia and even China.

Several articles and studies have already been published on the \#BlackProtest (Korolczuk 2016a; 2016b; Kubisa 2016, Majewska 2016, Narkowicz 2016, Chmielewska, Druciarek and Przybysz 2017, Król and Pustułka 2018). Despite the fact that the transnational dimension of the mobilization was widely acknowledged in Poland, as it was seen as a sign of the movement's huge success (Korolczuk 2016b), the majority of the articles focused on national protests and mobilization within the country. Demonstrations organized by Poles living outside of the 
country were overlooked. This study intends to fill this gap by focusing on the \#BlackProtest's transnational dimension. The inspiration for exploring this particular aspect of the mobilization came from the authors' own experience of the \#BlackProtest. Both authors had had the opportunity to observe and participate in the mobilization in different localities. One of us was situated in Poland and took part mostly in the protests organized in Cracow; the second engaged in and observed the movement from abroad in Oslo, Norway. This gave us a unique perspective on what was happening with respect to the feminist mobilization both in Poland and abroad, and inspired us to conduct a case study on how the \#BlackProtest was defined, understood, performed and negotiated by Polish migrant women living in different European cities.

Our main research questions for this study thus focused on what this act of solidarity, demonstrated by organizing \#BlackProtest internationally, meant for the organizers and what were the reasons behind their engagement? However, the analysis of the reasons behind transnational \#BlackProtest organizing revealed that it was insufficient to talk about this mobilization only in terms of transnational activism. As the characteristics of a transnational feminist diaspora emerged from the interview data it became clear that the \#BlackProtest mobilization should be understood as a case of transnational feminist diaspora in the making. We understand the diaspora not only in relation to ethnicity, or nationality, but as a heterogeneous cultural identity, that is constantly produced and reconstructed through a process of negotiations of intra-diasporic differences (Hall 1994, 235; Campt and Thomas 2008). The transnational dimension is primarily defined as social, cultural, economic, symbolic and personal ties that are maintained between a migrant community and their country of origin. This understanding makes the transnational \#BlackProtest organizing an event triggering the emergence of a transnational feminist diaspora. The key contribution of the paper is thus to demonstrate how in practice a feminist diaspora comes into being in the context of social movement mobilization.

Structurally, the paper is divided into several parts. It starts with a short description of the transnational \#BlackProtest's mobilizing structure. Next, we present the theoretical background of the study followed by a description of the data collection and the analysis process. The findings section presents the main reasons for Polish migrant women's engagement with \#BlackProtest organizing. Lastly, we discuss how and why these findings testify to the emergence of a transitional feminist diaspora.

\section{Transnational \#BlackProtest's mobilizing structures}

In this section we want to outline and contextualize the mobilizing structures that we believe enabled the transnational organizing of the \#BlackProtest. Apart from the already mentioned 
civil-initiative Ratujmy Kobiety (Save the Women) that was established in response to Stop Aborcji (Stop abortion) and which provided the immediate impulse for the \#BlackProtest mobilizing, three other aspects are important to consider in the study of the \#BlackProtest's transnational mobilization: the discursive opportunity structure (Mosca 2014) that existed in Poland prior to the mobilization; the connective leadership that linked people and helped frame and curate the stream of information that was produced by the movement (Della Ratta and Valeriani 2014); and the emotions that guided the mobilization.

\section{Discursive opportunity structure}

An important aspect of the transnational \#BlackProtest's mobilizing structure was the discursive opportunity structure that existed in the 'mediated public sphere' in Poland (Mosca 2014) and was made available to the movement due to a sequence of events that proceeded the mobilization. The emergence of the \#BlackProtest was preceded by a political shift that took place in Poland and that in 2015 led to a political crisis and the formation of a civic organization called Komitet Obrony Demokracji (KOD, the Committee for the Defense of Democracy). This crisis led to massive demonstrations organized by KOD across the country starting from December 2015, gathered at its highest peak approximately 50,000 demonstrators, and was highly covered by national and international media , . KOD was on one hand supported by the centre-right opposition parties (including Civic Platform (PO) that formed the previous government) and as such was supported by the liberal and commercial media. On the other hand, KOD opposed the actions led by the ruling majority government formed by the Law \& Justice party and as such was in conflict with the public media (controlled by the government) (Gober 2018). The \#BlackProtest could be interpreted as part of bloc recruitment (Diani 2013) since many of the KOD pro-democratic activists joined and even helped with the \#BlackProtest mobilization.

This context is important to show that a discursive opportunity structure existed in Poland that helped the \#BlackProtest secure an important place in the mediated public sphere. The mediated public sphere, as the indirect and mediated side of interaction between KOD and later the \#BlackProtest, and the political elites are at least as important for the study of social movements as the physical and direct confrontations that happen in the streets. As Mosco argues by quoting Koopmans (2004, 368 in Mosco 2014, 224) that news media are "the most relevant part of the mutual observation and interaction between protesters and authorities" and "Authorities will not react to - and will often not even know about - protests that are not reported in the media, and if they are reported, they will not react to the protests as they 'really' were, but as they appeared in the media." The \#BlackProtest was as such a case of media-driven mobilization and the international media played a signification role in its initial 
success (Walgrave and Manssens 2000). However, the mobilization was not only facilitated by mainstream media but was enabled by social media and bottom-up women-led mobilization that energized Poles across the country and internationally.

\section{Connective leadership}

The mass mobilization of the \#BlackProtest was facilitated by social media networks Dziewuchy Dziewuchom (Gals to Gals). The Gals to Gals in Warsaw gathered over 90 thousand members just a few hours after it was initially formed (Korolczuk 2016a). Soon other Gals to Gals networks were formed, including internationally - Gals to Gals in London, Gals to Gals in Berlin. Other initiatives, including Ratujmy Kobiety (Save the Women) also played an important role in social media bottom-up mobilization of supporters. The already mentioned KOD initially also played such a role. However, the most important role was played by Ogólnopolski Strajk Kobiet (All-Poland Women's Strike), an informal, non-partisan initiative of women, both non-affiliated and belonging to various women's organizations, which took on the role of connective leadership for the whole movement. Connective leadership is a crucial concept in the study of contemporary social movements (Della Ratta and Valeriani 2014). Its main function is to connect people and information and curate, pack and frame the information in a way that generates support for the mobilization both internally and externally. "Connecting people has a crucial meaning both inside the movement (where strong and weak ties coexist) and outside (where links are established with other activists of similar movements around the world, specifically 'diasporic' activists, 'slacktivists' and the mainstream media)" (Morris and Staggenborg 2004 quoted in Della Ratta and Valeriani 2014, 290). The All-Poland Women's Strike maintained and updated a website that framed the information about the movement and its activities and put it into context. As Della Ratta and Valeriani underline: "Giving the information a specific framework and putting it into context is a key factor in gaining national and international attention and credibility" (2014, 295). The AllPoland Women's Strike, in the persons of Marta Lempart and Natalia Pancewicz, also maintained a help desk, which coordinated and supported local activities and oversaw the movement's social media presence. Collective leadership emerged also at the regional level, in different smaller cities, where activists rooted in the communities became responsible for coordinating and mobilizing regional protests and demonstrations.

\section{Emotions}

Last but not least, an important aspect when considering the mobilizing structure of the transnational part of the \#BlackProtest was the emotionality of the mobilization in Poland. 
Emotions can play a crucial role in social movements' dynamics (cf. Flam 2005); to quote James Jasper (1997, 127), "Emotions give ideas, ideologies and identities, and even interests their power to motivate". We will argue that emotional aspects of the mobilization in Poland were an important trigger that not only ignited the transnational organizing of the \#BlackProtest but also played a crucial role in transforming identities of the migrants participating in the mobilization and had influenced their ways of engaging with the movement (cf. Collins 2001, Young 2005).

A diverse set of practices enabled the activists from Poland and migrants from across Europe to produce and sustain the \#BlackProtest mobilization for approximately six months. These included building networks, creating tools to communicate in a transnational space, communicating with the mass media and with the general public. These practices have already been analyzed by scholars (Kubisa 2016, Korolczuk 2016b) and as such will not be the focus of this article. Nevertheless, their existence needs to be acknowledged as an important context for the study we will present here on the transnational aspect of the \#BlackProtest mobilization.

\section{Theoretical perspective - feminist diaspora in the making}

We began our study with a conceptual framework embedded in social movement theory, as could be seen in the previous part of the article on transnational \#BlackProtest's mobilizing structures. This framework is useful when the \#BlackProtest mobilization amongst Polish migrants is theorized as a solidarity gesture with women in Poland and when the opportunity structures for transnational mobilization are analyzed. To that end, we began our study with questions on why the \#BlackProtest appeared abroad and what meanings the organizers assigned to it. However, collecting the narratives from the activists revealed that a different theoretical framework was needed to account for the process of a community formation, which was clearly happening in the context of the transnational \#BlackProtest. In this section we want to elaborate on the theoretical foundations that helped us argue that the transnational part of the \#BlackProtest mobilization testifies to the emergence of a transnational feminist diaspora.

Looking at how migrant women living in different European cities create transnational communities by demonstrating various linkages between their country of origin and the receiving societies, by negotiating their own feminist identities developed across borders, and by constantly reconstructing the boundaries of these communities, the concept of a diaspora became particularly useful. Definitions of a diaspora, on the one hand, have been often seen as 
problematic and criticized for assuming that the formation of the diaspora is inevitable ${ }^{1}$ once people have moved abroad (cf. Berns-McGown 2007/2008). The concepts have been also widely criticized for not addressing power relations and intersectional dimensions within ethnic and cultural communities (Campt and Thomas 2008, Sawyer 2008). On the other hand, since the 1990s diaspora and migration scholars, including feminist researchers, have argued that diasporic communities should be understood more broadly than only in relation to ethnicity or nationality. They propose seeing diasporas as imagined, cultural and identity collectives that go beyond ethnic and national aspects of the community. In such an understanding, belonging to a diaspora means recognizing and reflecting upon its own heterogeneity as well as negotiating its boundaries (Sökefeld 2006, Hall 1994). Ethnicity or nationality does not disappear from such a definition, but rather is perceived as entangled with other dimensions important for the formation of identities and communities, such as gender, class, religion, etc. (Paerregaard 2010). Furthermore, all these elements, crucial for the community formation, are expressed through various transnational practices, understood here as " [...] links that migrants establish to their country or region of origin, which allows them simultaneously to create new lives in the receiving society and maintain strong identity relations to the sending society" (Paerregaard 2010, 93). Importantly, the existence of the imagined feminist, transnational community does not require frequent transnational relations. Scholars have argued that the transnational dimension of the community is often symbolic and imagined (Sökefeld 2006, 268). However, for the diaspora to form a certain discourse has to arise and mobilize the community around it. Thus, the formation of a diaspora involves social mobilization and, as we have shown, should also be analyzed from the perspective of social movement theory. This does not mean that social movements and diasporas are the same social forms, nor does it mean that the formative phase of both is the same. On the one hand, diasporic practices do not need to pertain to social mobilization aiming at social and political changes. On the other, social movements are not inevitably related to migration. Yet, as Sökefeld argues, there are many parallels in the processes at work, and he continues to explain that the study of the diaspora can benefit from the study of social movements. Taking this reflection as our departure point, in this article we engage both social movement theories and diaspora concepts to explore the \#BlackProtest's transnational mobilization.

\footnotetext{
1 The issue of the inevitability of diaspora formation has been questioned by Stuart Hall (1996) who argued that when people are called "a community" (Sawyer 2008, 88) they may demonstrate their agency by deciding whether to participate in it or not. Similar to Hall, Martin Sökefeld in his analysis of diasporic communities focuses on its transnational dispersed yet collective character (Sökefeld 2006, 267). As such, the diaspora perceives itself as a community. As Sökefeld notes, migrants do not automatically form a diaspora simply by the fact of becoming migrants. They may become a diaspora by developing a new imagination of their community, even years after the migration took place (Ibid., 267). To talk about a diaspora we thus need a sense of belonging to a community.
} 
Following Hall's notion of diasporic communities (1994, 235) defined "[...] not by essence or purity, but by the recognition of a necessary heterogeneity and diversity; by a conception of 'identity' which lives with and through, not despite, difference; by hybridity", we want to address an internal heterogeneity of the feminist transnational diaspora, by looking at motives standing behind the decision of joining the movement, and by exploring the transnational aspects of the feminist community (embedded in contexts of both receiving and sending countries). Building upon Paerregaard's argument $(2010,92)$ we offer to see diasporic, feminist groups of Polish migrants evolving around the \#BlackProtest as those communities, "[...] that are constantly negotiated and contested and that exclude as much as they include, rather than as entities that are bounded and homogeneous and that automatically embrace all migrants from a particular nation". We explore transnational feminist practices of selforganizing with regards to reproductive struggles in Poland as a consequence of both sharing similar migration history and feminist ideas at the same time. We thus propose to understand a transnational, feminist diaspora through three main dimensions important for defining diasporas in general:

1. A transnational dimension, which enables the analysis of the entanglements between a country of origin and a receiving country, often manifested in various practices undertaken by migrants to sustain their relations with the country they come from, and at the same time introduced to build stronger links with the receiving society;

2. Identity formation and negotiation processes, which helps to explore how both feminist and transnational aspects of the activist's identities are formed and navigated by them in everyday mobilization;

3. An internal heterogeneity, which points to the boundaries created by the feminist diaspora by showing how certain conflicts lead to the inclusion of some ideas, practices and groups in the diaspora, and to the exclusion of others.

As we will show in the findings and discussion sections, the experience of mobilization reported by migrant women involved in the organizing of the \#BlackProtest did testify to the formation of a new imagined transitional community, which unified feminists living in different geographical locations, yet having strong relations with Poland (Sökefeld 2006, 267). Sökefeld's and Hall's definitions of diaspora thus helps us argue that the \#BlackProtest can be perceived as a case of transnational feminist diaspora in the making. We argue that by identifying themselves as "a Polish feminist abroad" or "a Pole and a feminist living abroad", the activists demonstrated not only solidarity gestures with women in Poland, but actively participated and negotiated their identities, bonds and relations with their country of origin and the Polish feminist movement, and as such formed a transnational feminist diaspora. 


\section{Data collection and analysis}

This study was conducted under the framework of a small, self-financed research project carried out by the authors between May and August in 2017. Six in-depth interviews were conducted with Polish migrant women involved in organizing \#BlackProtest solidarity demonstrations in Oslo, Norway (two activists), London, UK (two activists), Berlin, Germany (one activist) and Brussels, Belgium (one activist).

To select the cities that were included in the study the authors have analyzed Facebook event pages created for each demonstration that was organized as part of the 3 October 2016 \#BlackMonday protest. The decision to focus on \#BlackMonday was motivated by the fact that it was the first mass demonstration of the \#Black Protest that took place in over 200 cities and towns in Poland and in 49 cities in 29 countries in Europe and elsewhere, and it was well documented. The full list of the sites where the protests were organized, together with links to their Facebook event pages was published by connective leaders - the Ogólnopolski Strajk Kobiet on their website (All-Polish Women Strike). The authors looked at the number of people who indicated their willingness to participate in the event. These numbers obviously did not correspond with the number of the actual protesters but nevertheless provided a good indicator of the demonstration site's visibility and the organizers networks, both in Poland and abroad. The Facebook event pages that were contacted to participate in the study had generated an above average interest from the public. The average interest for the 49 cities was 562 potential participants with the median at 204 , and the sites selected for the study had an average of 1372 potential participants with the median at 947. An additional criterion was applied to select the sites; for comparison reasons we were interested in demonstrations organized in different European capital cities.

The authors contacted the administrators of the selected Facebook event pages, who in most cases were also the organizers of the demonstration, to participate in the study. Most responses were very positive as all women felt it was important to reflect on their experiences of organizing the \#BlackProtest abroad. Due to some logistical problems, not all interviews were eventually conducted, but the six in-depth interviews were comprised of women who were white, of Polish origin, with higher education and a median age of 42.5. All of them had rather high cultural capital but they represented different class backgrounds and two of the interviewees represented working-class migration. The time they have spent living outside of Poland ranged from 5 to 24 years. All interviews were conducted in Polish via Skype and were recorded and transcribed. The interviews lasted from 41 to 108 minutes, with the average being 72 minutes. Pseudonyms are used in the article and we avoid identifying individual women simultaneously with the city they represent, as some of their biographical details might make their identification possible. Considering some of these women are present in the media and 
stay active on social media it is important to make sure that their anonymity is properly maintained. As we were interested in understanding the motives behind the transnational dimension of the \#BlackProtest, the main topics discussed during the interview included questions on how and why they got involved in the organizing of the \#BlackProtest; if they felt they belonged to a social movement and if their activism was important for Poland; how was the protest organized? Did they keep in touch and did they receive any help from the activists in Poland; and what reaction did the traditional media have to their protest. Both open and theory-driven ways of coding the interviews were applied, following the principles of a thematic analysis (cf. Flick 2006). The theory-driven codes were primarily based on social movement theories, providing the following main categories for coding: reasons for engaging in the \#BlackProtest, the main aims behind organizing the protests, experiences related to the protests, important social actors involved in the activism, ways of self-organizing (communicating strategies, leadership, contacting media, etc.). Open coding contributed to reflective reading of the material and looking for new categories emerging from the narratives. In this phase, the researchers read the transcripts as text looking for recurring themes, similarities and differences. This step enabled the researchers to reach out for a new conceptual framework which led to the notion of the diaspora in the realm of the \#BlackProtest.

\section{Findings}

Women who stood behind the \#BlackProtest demonstrations organized outside of Poland had different reasons for their activism. Their backgrounds differed in regards to previous experiences of social organizing but most of them had been involved in feminist activism before the \#BlackProtest. Some had had these experiences from when they were still living in Poland and abandoned activism for a couple of years after having emigrated, others continued engaging with feminist social organizing after emigration, yet others discovered the need for activist organizing only once they became migrants and engaged either with the Polish migrant community or local organizations and local feminist networks. The high media visibility of the \#BlackProtest had all of the interviewed women reflect on their relations with Poland and Polish society and despite the different experiences with activism, almost every interviewee depicted her decision to engage in \#BlackProtest organizing as a certain turning point or an important moment in her life.

The reasons for why these women decided to get involved with organizing of the \#BlackProtest could be grouped into three main categories: feelings of responsibility, personal experiences, and anger as the main emotion that framed the whole movement. These categories are created for the purpose of organizing the findings of the study. They did not emerge as distinct categories from the interviews, but rather overlapped and interlocked with other 
motives and with each other. Still, these were the resounding motives for joining the organizing of the \#BlackProtest.

\section{Feelings of responsibility}

One of the reasons for getting involved with \#BlackProtest organizing evolved around a sense of personal responsibility the interviewees felt for women's rights in general, for women in Poland and finally for Poland as a country.

Alina connected her \#BlackProtest activism to a strong sense of personal responsibility for women's reproductive rights. She emigrated from Poland 13 years before the \#BlackProtest and had been involved in various projects and campaigns aimed at and organized with women from the Polish migrant community ever since. Despite her previous activism and engagement with the Polish migrant community, the \#BlackProtest left her reflecting on her own privileged life and a sense of indebtedness overwhelmed her. Having lived for many years in a secular state where women's rights are respected left her dismayed that in her country of origin there are still people with power to control or limit women's reproductive choices. In additional to her rights being respected by her host country she underlined the good financial situation of her own family. The privileged social position that she occupied in the society, in her opinion, enabled her activism and Alina explicitly pointed out that she became an activist because she did not have to overcome any structural obstacles. Such personally declared biographical availability (McAdam 2015) was undeniably an important factor for her becoming a women's rights activist, however it was the strong sense of personal responsibility that drove her engagement with the \#BlackProtest. Similarly, Agata, who emigrated from Poland 10 years before the \#BlackProtest, became active in the movement because of a moral sense of responsibility for other women and specifically for one of her two daughters, who still lives in Poland.

Ewa's motivation to join the \#BlackProtest, similarly to Alina and Agata, was driven by her explicit feminist convictions - she wanted to support women's reproductive rights. However, the focus of her and her fellow activists' organizing was predominately on Polish migrant women and women living in Poland. Their sense of responsibility for helping those women who are still living in Poland drove many of the activities her feminist network organized in the host country. Ewa explained,

Polish women are mobilizing out of fear. We are doing this [abroad] because we can't believe that in the XXI century somebody can still have such ideas. Polish women are happy we are supporting them. Sisterhood is great. We have to be grateful to Zuckerberg for Facebook and to Kaczyński [the leader of the Law \& Justice party] for 
mobilizing women. Something wonderful will come out of this crisis. (Ewa, Skype interview, 2 August 2017)

The goal of Ewa's feminist network was to spread knowledge about the situation of women in Poland amongst the migrant community but also to bring hope and positive examples of women's organizing back to Poland. As she put it: "We take up small educational actions, we write in Polish, we want Polish women to read this." Their actions were not limited to street protests. They were also organizing conferences, screenings of feminist movies, and held a mini Congress of Polish Women, where they have invited Krystyna Kacpura, President of a Polish NGO Blue Line, which works against domestic violence in Poland.

For Agata it was also the feeling of responsibility for the fate of Poland that drove her towards \#BlackProtest organizing. Agata's teenage years happened during the political and economic transformation Poland went through at the beginning of the 1990s and she remembers very vividly the feeling of relief and hope that her country would finally be free and democratic. Agata strongly believed her daughters would grow up in a modern and democratic state and the recent political changes and the attempt of the ruling Law \& Justice party to restrict women's right to abortion left her bitter and disappointed. As a Pole living abroad, she said she felt responsible for demonstrating to her new fellow citizens that not all Poles support the Polish government's decisions. "I feel Polish and I identify with what is happening in Poland" - Agata stressed and she went on to explain:

\footnotetext{
I was very proud of all the changes Poland went through in the last two decades. And at some point, I started feeling ashamed. I felt responsible for what was happening in the country. I didn't have to. I never voted for them [the ruling party], but I feel a moral obligation as a Pole representing other Polish women it this country and Poles in general. As a Pole I also participate, for example, in initiatives supporting the refugees. Because I feel ashamed of the decision of the Polish government not to help the refugees. This is an important moment to show that we don't accept what they are doing. (Agata, Skype interview, 5 August 2017)
}

\section{Personal experiences}

Another resounding motive for joining the organizing of the \#BlackProtest evolved around personal experiences. Agata, for example, recalled a crisis situation she went through as a teenager. During that difficult period, she received psychological counseling from two psychologists, who she believes helped her regain a sense of control over her life. The attempt of the current government in Poland to cut funding to women's organizations and support centers left her very upset. From her personal experience she knew very well how important 
such organizations are and how without them women's struggles will be even more painful and difficult. Similarly to Agata, Anna, who emigrated 10 years ago, decided to join the organizers of the \#BlackProtest based on her personal experience. In the interview Anna re-called that her views on abortions rights changed dramatically from when she was a teenager living in Poland in the 1990s to when as a mature migrant woman, she tried to become pregnant while undergoing in vitro fertilization treatment (IVF). Since the discussion around abortion and access to IVF are intertwined in the Polish context, her experiences with \#BlackProtest organizing were strongly tied to her own experiences. Anna explained: "Because of the fact that I was trying to have a baby, I believe that every woman has the right to have a child, but at the same she has the right to not want to have a child" (Skype interview, 15 June 2017)

\section{Anger as the driving emotion of the movement}

Anger and the emotionality of the movement was another important factor that facilitated the activists' decision to get involved in \#BlackProtest organizing. Monika, whose feminist activism started in Poland before her migration 5 years ago, found herself inactive and not really involved in any collective actions in her new country, apart from participating in a few feminist demonstrations. She did, however, form a small informal friendship-based network of Polish feminists, with whom she eventually started organizing the \#BlackProtest. Monika explained,

For me the most important trigger was the fact that I was here while in Poland there were these horrible things happening. There was this wave of terrible news everywhere on social media [...] I just couldn't stand it, I had this need to express myself. I remember we [her small feminist network] were talking on the phone, saying "What the fuck is going on? We have to do something." (Monika, Skype interview, 24 August 2017)

Similarly, anger directly motivated Anna, for whom the \#BlackProtest meant in fact engaging in social activism for the first time in her life.

I went to a demonstration, because I was angry and I somehow felt this sisterhood. I have never been engaged in anything like this, I have not participated in any protest. [...] Right now I am just happy I don't live in Poland and my kids won't have to live there as well. (Anna, Skype interview, 15 June 2017)

Agata's engagement with the \#BlackProtest organizing, as was already mentioned, was fueled by a sense of shame for what was happening in the country. At the same time, however, she 
felt passionate about mobilizing resistance amongst other migrants living in her city. Agata explained,

I was very angry that nothing was happening in my city. I was posting [on social media] passionately, trying to mobilize other women to act together. But they were not very interested in doing anything. I believe they felt they are safe living abroad and that what is happening in Poland doesn't concern them. But I didn't give up... I was so angry that eventually I managed to mobilize a group and our actions gained a lot of attention from the international media and support from the local activists. (Agata, Skype interview, 5 August 2017)

The different reasons behind \#BlackProtest organizing by migrant Polish women revealed that, in terms of the individual biographies, the pro-choice mobilization has been motivated mainly by a sense of responsibility for what was happening in Poland as a country, responsibility for the women who live in Poland and a sense of caring for their futures, as well as responsibility for the future of their own children and women's rights more broadly. Another important category of motives included personal past experiences related to reproductive rights and women's health. And lastly emotions triggered by the events in Poland had driven \#BlackProtest organizing abroad. The activists' experiences of daily life were rooted in Western democratic countries where women's rights (including reproductive rights) are perceived as guaranteed and unthreatened and comparing their own situation with the situation in Poland made many of them angry. This anger drove their mobilization.

\section{Discussion and conclusions}

An analysis of the reasons Polish migrant women had for getting involved with the \#BlackProtest organizing revealed the need these women had for negotiating their own definition of feminism and their place within the feminist movement. In the discussion we aim to argue that the \#BlackProtest spearheaded the process of a transnational feminist diaspora formation. Our argument is supported by three dimensions of such a community:

1. Negotiating transnational feminist identity;

2. Handling and redefining relations with the Polish feminist movement and, more broadly, with the country of origin;

3. Internal heterogeneity and conflicts over the diaspora boundaries.

These dimensions reveal how through forming and negotiating feminist identities across borders, through reconstructing and sustaining relations with the country of origin, and through establishing the boundaries of the community, a diaspora is constructed by the activists. 


\section{Negotiating transnational feminist identity}

The interview material showed very clearly that the organizers of the \#BlackProtest living outside of Poland had a strong sense of belonging to a newly formed community. As we argued in the theoretical part of this paper, forming a diaspora requires producing and sustaining specific identities, which are, however, rarely stable and taken for granted in everyday practices (Hall 1994, Paerregaard 2010). The imagined diasporic community does not assume that a shared identity, which is a significant element of this concept (Cohen, 1997), is unproblematic (Hall 1994). Quite the contrary, it can be bitterly disputed, as was the case in our study.

Some of the interviewees had been involved in feminist activism before migration, but experiences of organizing the \#BlackProtest triggered questions about their place and position in the feminist mobilization. A good illustration of these kind of negotiations and reflections comes from the activists in London. One of the interviewees describes her commitment to the movement through the lens of a change that the \#BlackProtest evoked in her. Her history of engaging in feminist activism began after she emigrated from Poland. In London, over the years, she was actively involved in various feminist events. Because her experiences of feminist selforganizing, knowledge, and ideas were rooted primarily in the English context, she used to describe herself as "an English feminist." The experience of organizing the \#BlackProtest had her question the meaning of her symbolic and physical "separation" and the distance she kept from Poland and Polish feminism. She explained,

Finding a Polish feminist in me had a deep meaning for me. Although I visit Poland regularly, I read about Poland, the fact is I had been doing English feminism with English feminists. These last events made a great change in me, [it meant] a sort of opening to the world, admitting to myself that maybe I separated myself from Poland. Rightly so or not, I had separated myself from Poland. But I am Polish after all. I come from Poland. And these events helped me to find my own place in feminism, because through many years, I've worked for many organizations and I never felt I fitted there entirely. This Polish feminism absorbed me intensely. I think this is my place now.

The emotions that she experienced during the protest had a transformative character (cf. Collins 2001, Young 2005): they enabled a feeling of solidarity with women in Poland, but also reconstructed her own identity and definition of feminism. Ever since she got involved in \#BlackProtest organizing, she started to see her feminist identity in a more complex way than before and merged her past ways of defining feminist activism with her self-awareness of being a Pole and its impact on her activist identity. She started to link feminist ideas with the particular situation of women in Poland and her own nationality. The fear that a total ban on abortion would be introduced in her country of origin and the emotions that accompanied these events provoked a visible change in her way of framing feminist activism. Her sense of belonging to the English feminist community has been replaced to some extent by a sense of belonging to 
a transnational community, in which fighting for and with Polish women for their rights was a crucial mobilizing factor. While the feminist ideas guiding her actions are still embedded in the English context, the actions themselves became more centered on women's rights in her country of origin. Similarly, the second activist from London argued her feminism was also born during her stay in England, however it was not done with and amongst English feminists. The motivation for her early involvement in the feminist struggle came from a group of women who were living in Poland but with whom she met online regularly. These intensive online conversations with other Polish women helped her "feel at home" and find her space within the feminist diaspora. This mobilization practice - communicating constantly and sharing ideas online across borders - seemed to be pivotal for her later engagement in the movement. She recalled,

When I first came here 24 years ago, I tried to establish some relationships with the Polish migrant community, but it didn't really work. I didn't find my soulmates amongst other migrants. And then I found this Polish chat group, called "Women over 30" (it was based in Poland) where finally I felt at home. This group was very important to me and we are still in touch after 13 years. Many of us remain active in feminism until this day, especially now during the \#BlackProtest in Poland.

Experiences with \#BlackProtest organizing provoked the transformation of the Polish female migrants' self-involvement in feminism, impacted their self-organizing strategies, and had the activists re-negotiate their transnational feminist identities. Rejecting the separation between themselves, Poland and other Polish migrant communities and taking conscious steps towards more transnational activism, yet remaining critical to the concept of a Polish identity, revealed how a transnational feminist diaspora was being formed. Based on feminist ideas and the need to support women's struggles for their reproductive rights, the activists' engagement with Polish and non-Polish feminists goes beyond the \#BlackProtest, making the argument about a transnational feminist diaspora in the making even stronger. Following the \#BlackProtest organizing, the activists have set up various groups which published updates and organized events around different feminist issues, either only in Polish or both in Polish and in the local language, but always with a focus and links to the Polish feminist movement and the Polish migrant feminists. Sometimes the linkages also included the local feminist community. For example, in London an informal group FARSA - Feminist Activists of Royal San Escobar Association $^{2}$, - was established and performed various actions on the Internet and in public

\footnotetext{
${ }^{2}$ Farsa in Polish means mockery. Both the abbreviation of the group's name and the name itself is meant to ridicule the Polish government. San Escobar is a reference to a non-existent country, which serves as a reminder of a blunder by the Polish Minister of Foreign Affairs, Witold Waszczykowski. The minister told reporters that
} 
spaces. Activists from Brussels established a non-governmental organization called Elles sans frontières (Women without borders), which among other activities organized the Congress of Polish Women in Brussels. In Oslo, the activists formed an informal group Kvinner står sammen. Kobiety razem (Women together), which blogged about women's rights, both in Polish and in Norwegian. Similarly, the activist from Berlin started her own group which mobilized support for the \#BlackProtest through social media and a blog.

Through these various practices of self-organizing the activists negotiated their sense of belonging to the feminist community, their identities as feminists, migrants and Poles, but also ensured the persistence of the diaspora. The hybridity of feminist ideas taken from both Poland and their host countries seems to be central to shaping the transnational feminist diaspora (cf. Hall 1994).

\section{Handling and redefining relations with the Polish feminist movement}

The newly found identity of belonging to a feminist transnational diaspora did not come without a struggle. Diasporic organizers of the \#BlackProtest found themselves negotiating their own place within the feminist diaspora and redefining relations with the Polish feminist movement. These negotiations varied from city to city and depended very much on the type of relations the activists had had with the wider Polish migrant community and feminists in Poland, and on their own understanding of what the role of the feminist diaspora could be. The complex and ambivalent relations with the center of the protests - the movement and activists situated in Poland - can be demonstrated with the following example.

Although the mobilization in Poland was, as we already argued, the mobilizing structure for these diasporic feminist responses, the activists had very different experiences with the center, both in regards to their needs and wishes to maintain relations with the \#Black-Protest organizers from Poland. Ideas were also very different in regards to where and what the center of the protest actually was. For one of the activists from Berlin, for example, it was very important to maintain personal relations with the established feminist community in Poland. She was not interested in communicating only with the actual organizers of the \#BlackProtest, but invested time and resources in maintaining relations with the broader Polish feminist community. She traveled to Poland as frequently as possible, made sure to participate in important feminist events, such as the Congress of Polish Women, demonstrations and conferences and continued to build her personal network. She felt that such devotion was not sufficiently rewarded, hence she was disappointed with the support she, as a representative of

in a bid for a non-permanent seat for Poland on the UN Security Council, he met with officials from various countries, including from San Escobar. 
the Polish feminist diaspora, received from the center. Despite the fact that during her visits to Poland she was "patted on the back" as she put it (a gesture of appreciation for her actions), she felt that in the moments when real advice and support were needed they were not available to her. She explained,

\begin{abstract}
Multiple times I felt bitter that we are doing so much here in Berlin, but that we are forgotten in Poland, treated as something worse. I don't know where it's coming from. Maybe it's our Polish mentality to treat Poles who are living abroad as lesser Poles or something like that.
\end{abstract}

Together with two other Polish women she responded to everything that was happening in Poland by organizing solidarity events in Berlin. This was their group's own initiative and as such it was not directly coordinated with the \#BlackProtest organizers from Poland. With some regret the interviewee reflected that the only help Berlin organizers received from Poland was with obtaining access to the protest's logo. Similar reflections appeared in the narratives of the women situated in Oslo. Although one of them had strong informal relations with feminist organizations and groups located in Poland, both interviewees underlined that organizing the protests in Oslo was done without support or even knowledge from the Polish side. Unlike the activist in Berlin, however, the feminists from Oslo did not feel the need to maintain close relations with the center of the \#BlackProtest organizing, and limited their communication to sharing links to their events on the center's social media pages. Organiz-ers of the \#BlackProtest from London felt satisfied with the relations they have maintained with the center. Despite the fact these, similarly to Oslo, were mostly limited to sharing links to events organized via social media and commenting on each other's posts with pictures and updates about the happenings in London, reflection about the relationship with the center was rather positive. The relationship between the diasporic \#BlackProtest organizers and the center of the protest was maintained through the connective leaders, the Ogólnopolski Strajk Kobiet (All-Polish Women's Strike) website and with some disruptions through social media networks, mainly the Dziewuchy Dziewuchom (Gals to Gals). The feminist diaspora both obtained information about mobilization plans in Poland and updated the center about their solidarity mobilization activities in London, Oslo, Berlin and Brussels. In addition to keeping contact with the \#BlackProtest organizers in Poland, the activists from London maintained contact with feminists who were mobilizing around reproductive rights in other countries: Italy, Argentina, Ireland, Malta, and South Korea, to name just a few countries that had experienced backlash against reproductive rights around the same time as Poland $\mathrm{did}^{3}$. The support they

\footnotetext{
${ }^{3}$ This may suggest that there is potential for expanding the transnational diaspora beyond the two dominant contexts of a country of origin and a host country, but this hypothesis requires further research.
} 
offered each other was also facilitated by social media and came down to occasional messages and "liking" and commenting on each other's social media activity.

Against this background, we argue that the relations the activists maintained with the center of the protest - understood here both as symbolically referring to the Polish movement and the everyday, yet often ephemeral, transnational practices between diasporic communities and feminist activists in Poland - required ongoing negotiations, which in fact produced and maintained the transnational feminist diaspora.

\section{Internal heterogeneity and conflicts over the diaspora's boundaries}

The exploration of the feminist diaspora that emerged through the transnational \#BlackProtest organizing revealed its internal heterogeneity and conflicts over the diaspora's boundaries. Debating and negotiating the diaspora's identity, its goals and visions are productive for the community as it creates a heterogeneity of voices, and allows for a variety of roles and positions to emerge within the imagined community. But it also allows for inclusion of certain voices and positions within the diaspora, leaving others at the diaspora's margins and yet excluding still others from the community all together. These practices based on inclusion and exclusion were salient in the \#BlackProtest activism and provoked internal conflicts and disputes both within the movement in Poland and within the transnational diaspora. Interestingly, all interviewed feminists from London, Oslo, Berlin and Brussels eventually decided to set up their own groups, as with time a conflict emerged within the social media networks that provided connective leadership for the diaspora. The conflict concerned the end goal of the protests. Some women joined the movement to defend the status quo of the abortion law in Poland; others joined to mobilize for its liberalization. The transnational feminist diaspora defended its identity as supporters of the liberalization of the currently existing abortion law in Poland. This led to the Polish feminist migrants either excluding themselves or, as was the case with Berlin, being excluded from some of the social media networks that were set up to facilitate the mobilization. Because of these divisions, the center and some of the social networks were sometimes depicted by the diaspora as more conservative and reserved with respect to feminist demands. As one activist from London explained,

Some women from the network Dziewuchy Dziewuchom w Londynie (Gals to Gals in London) opted primarily to protest against restrictions of the existing law. They told us that they supported liberalization as a utopian goal, but had decided to settle for a more realistic objective. For me it was surprising that they didn't want to take the struggle further and demand a full liberalization of the law. Because for me it's clear that abortion should be legal. I understand why it might be less obvious in Poland. But here it is obvious, abortion is normal here and the society is used to it. 
Another issue raised during the interviews concerned the question of the class dimension of the \#BlackProtest and, more broadly, of the transnational feminist diaspora. For example, one of the already mentioned interviewees suggested that her relatively good and stable economic and social position made her biographically available to engage in collective actions. Other interviewees have also noticed their difficulties with engaging working-class Polish migrant women in the \#BlackProtest. Because of that, the working class was sometimes described by the feminist diaspora as a separate society with different values and goals in their lives. One of the interviewees observed: “They [working class Polish female migrants] don't even say 'hello' to me, although they can hear me speak Polish. This is a class gap. I'm active in a group of let's call it 'conscious migration'. These two groups don't mix with each". Similar to how the diaspora negotiated its imagined feminist identity, which was visible in the conflict over the goals of the protest, the Polish diaspora ("Polonia") was depicted by the feminist community as rather conservative and not interested in mobilizing for women's rights. The activists thus drew clear boundaries not only between themselves - the transnational feminist diaspora - and the other activists, but also between themselves and the traditional diasporic groups.

Our research looked at the \#BlackProtest organizing in various European cities by Polish feminist migrants who were triggered by the \#BlackProtest taking place in Poland. When we analyzed the reasons Polish migrant feminists had for joining the movement and at their ways of self-organizing the \#BlackProtest, the transformative character of this solidarity activism became apparent. In this paper we claimed that organizing the \#BlackProtest abroad resulted in the emergence of a transnational, feminist diaspora. We argued that joining the movement contributed to the activists' forming and negotiating a new identity for themselves - that of a transnational feminist. It also had them seeking new strategies for managing transnational relations, including connections with the center of the \#BlackProtest, the feminist movement in Poland. Finally, organizing the \#BlackProtest abroad initiated a process that has shaped the boundaries of the emerging feminist community. As we demonstrated in the theoretical part of the paper, the belonging of people to a larger community may refer to specific events that are then defined as incidents that affect the whole community and trigger the formation of a diasporic community (Sökefeld 2006). The \#BlackProtest diaspora did emerge in the context of migration, but was not directly triggered by the fact of being on the move. Despite the fact it emerged in the context of living abroad, it was developed in response to a specific event (the \#BlackProtest mobilization in Poland). Thus, the \#BlackProtest mobilization resulted, we argue, in the formation of a transnational, feminist diasporic imagination of community, however fragile and durable this community may prove to be. 


\section{References}

Berns-McGown, Rima. 2007/2008. "Redefining »Diaspora«: The Challenge of Connection and Inclusion." International Journal 63(1): 3-20.

Campt, Tina, and Deborah Thomas. 2008. "Gendering diaspora: transnational feminism, diaspora and its hegemonies." Feminist Review 90(1): 1-8.

https://doi.org/10.1057/fr.2008.41

Chmielewska, Marta, Małgorzata Druciarek, and Izabela Przybysz. 2017. Czarny Protest. W strone nowego "kompromisu aborcyjnego"? Warszawa: Instytut Spraw Publicznych.

Cohen, Robin. 1997. Global Diasporas. An Introduction. London: UCL Press.

Della Ratta, Donatella, and Augusto Valeriani. 2014. "Remixing the Spring! Connective Leadership and Read-Write Practices in the 2011 Arab Uprisings." In Communication Rights and Social Justice. Historical Accounts of Transnational Mobilizations. Eds. C. Padovani and A. Calabrese. London, UK: Palgrave Macmillan: 288-304.

Diani, Mario. 2013. "Bloc Recruitment." In The Wiley-Blackwell Encyclopedia of Social and Political Movements. Eds. D.A. Snow, D. della Porta, B. Klandermans, D. McAdam. Oxford: Wiley-Blackwell.

Flam, Helena. 2005. “Emotion's Map: a Research Agenda." In Emotions and Social Movements. Routledge Advances in Sociology. Eds. H. Flam and D. King. London-New York: Routledge: $19-40$.

Flick, Uwe. 2006. An Introduction to Qualitative Research. London. Thousand Oaks, California: Sage Publications

Gober, Greta. 2016 a. "Polarization in Poland. Commentary." Baltic Worlds 9(4): 88-89.

Gober, Greta. 2016 b. "International Ultra-Conservative Anti-Abortion Lobbying. Who is Behind the Anti-Abortion Bill in Poland." Kvinnefronten October 7.

Gober, Greta. 2018. Instytucja medialna przezpryzmat ptci. Gdańsk: Wydawnictwo Naukowe Katedra.

Hall, Stuart. 1994. "Cultural Identity and Diaspora." In Colonial Discourse and Post-Colonial Theory. Eds. P. Williams and L. Chrisman. New York: Columbia University Press: 392 403.

Jasper, James. 1997. The Art of Moral Protest. Culture, Biography, and Creativity in Social Movements. Chicago: The University of Chicago Press.

Koopmans, Ruud. 2004. "Movements and Media: Selection Processes and Evolutionary Dynamics in the Public Sphere." Theory and Society 33: 367-391.

Korolczuk, Elżbieta. 2016a. "Mass Mobilization Against the Ban on Abortion in Poland." Baltic Worlds 9(4): 88-89.

Korolczuk, Elżbieta. 2016b. "Explaining Mass Protests Against Abortion Ban in Poland: the Power of Connective Action." Zoon Politikon 7: 91-113.

Król, Agnieszka, and Paula Pustułka. 2018. "Women on Strike: Mobilizing Against Reproductive Injustice in Poland.” International Feminist Journal of Politics 20(3): 366-384. https://doi.org/10.1080/14616742.2018.1460214.Kubisa, Julia. 2016. “Odzyskajmy Polskę dla kobiet!" Krytyka Polityczna October 10. Retrieved from: https://krytykapolityczna.pl/kraj/odzyskajmy-polske-dla-kobiet/ (accessed 20.04.2019).

Majewska, Ewa. 2016. "Słaby opór i siła bezsilnych. \#CzarnyProtest w Polsce 2016." Praktyka Teoretyczna November 10. Retrieved from: 
http://www.praktykateoretyczna.pl/ewa-majewska-slaby-opor-i-sila-bezsilnychczarnyprotest-kobiet-w-polsce-2016/ (accessed 15.04.2019).

McAdam, Dough. 2015. "Recruits to Civil Rights Activism." In The Social Movements Reader: Cases and Concepts. Eds. J. Goodwin \& J.M. Jasper. Chichester, West Sussex, UKMalden, MA: John Wiley \& Sons Inc.: 65-75.

Morris, Aldon. D., and Suzanne Staggenborg. 2004. "Leadership in Social Movements." In The Blackwell Companion to Social Movements. Eds. D. A. Snow, S. A. Soule and H. Kriesi. Oxford-Malden, MA: Blackwell.

Mosca, Lorenzo. 2014. "Bringing Communication Back In: Social Movements and Media." In Communication Rights and Social Justice. Historical Accounts of Transnational Mobilizations. Eds. C. Padovani and A. Calabrese. London, UK: Palgrave Macmillan: 219-234.

Narkowicz, Kasia. 2016. "Czarny Protest: How Polish Women Took to the Streets.” Open Democracy October 11. Retrieved from: https://www.opendemocracy.net/en/caneurope-make-it/czarny-protest-how-polish-women-took-to-streets/ (accessed 20.04.2019).

Paerregaard, Karsten. 2010. "Interrogating Diaspora: Power and Conflict in Peruvian Migration." In Diaspora and Transnationalism. Concepts, Theories and Methods. Eds. R. Bauböck and T. Faist. Amsterdam: Amsterdam University Press: 91-107.

Sawyer, Lena. 2008. "Engendering »Race« in Calls for Diasporic Community in Sweden." Feminist Review 90: 87-105.

Sökefeld, Martin. 2006. "Mobilizing in Transnational Spaces: a Social Movement Approach to the Formation of Diaspora." Global Networks 6(3): 265-284.

Walgrave, Stefaan, and Jan Manssens. 2000. "The Making of the White March: The Mass Media as a Mobilizing Alternative to Movement Organizations.” Mobilization 5(2): 217 239. 
Greta Gober - defended her PhD in cultural studies with a specialization in media from the Warsaw University of Social Sciences and Humanities in Poland. During her PhD she was a Guest Researcher at the Centre for Gender Research at the University of Oslo and a Fulbright Visiting Scholar at the Department of Gender and Women's Studies at the University of California, Berkeley. She is the author of The institution of the media through the prism of gender (2018) and a Handbook on Working Towards Gender Equality in the Media (2019). She is currently a Postdoctoral Fellow at the Department of Media Studies, Stockholm University where she is working on a project exploring organizational responses to online harassment of female journalists.

\section{ADDRESS:}

Department of Media Studies

Section for Journalism, Media and Communication (JMK)

Stockholm University, Karlavägen 104

115-93 Stockholm, Sweden

EMAIL: greta.gober@ims.su.se

Justyna Struzik - received her $\mathrm{PhD}$ in sociology from the Institute of Sociology at the Jagiellonian University in Cracow, with the thesis "Queer Movements in Poland". Currently, she is a Postdoctoral researcher on the project "Disentangling European HIV/AIDS Policies: Activism, Citizenship and Health". She has participated in numerous research projects focused on discrimination and inequalities in an intersectional perspective, with special attention given to sexual identity, gender, and place of residence. She co-authored Różnym głosem. Rodziny z wyboru w Polsce (In Different Voices. Families of Choice in Poland, 2017, with Joanna Mizielińska and Agnieszka Król) and authored Solidarność queerowa. Mobilizacja, ramy i działania ruchów queerowych w Polsce (Queer Solidarity. Mobilisation, Frames and Actions of Queer Movements in Poland, 2019).

\section{ADDRESs:}

Instytut Socjologii UJ

Ul. Grodzka 52

31-044 Kraków

EMAIL: justyna.struzik@uj.edu.pl

CitAation: Gober, Greta, and Justyna Struzik. 2018. "Feminist Transnational Diaspora in the Making. The Case of the \#BlackProtest" Praktyka Teoretyczna 4(30): 129-152.

DOI: $10.14746 /$ prt.2018.4.5 
AUTOR: Greta Gober, Justyna Struzik

TYTUŁ: Feministyczna transnarodowa diaspora w działaniu. Przypadek \#CzarnegoProtestu

ABSTRAKT: Autorki artykułu omawiają społeczną mobilizację wokół \#CzarnegoProtestu wśród polskich migrantek mieszkających w czterech europejskich miastach. \#CzarnyProtest był najwyrazistszym przykładem ruchu o prawa kobiet w najnowszej historii Polski. Główne pytanie badawcze prezentowanego studium dotyczy znaczeń przypisywanych zagranicznym protestom solidarnościowym przez ich organizatorki. Analiza motywów skłaniających do organizowania \#CzarnegoProtestu za granica pokazuje, że mobilizacja ta wykracza poza ramy transnarodowego aktywizmu. Teoretyczna rama artykułu powstała w oparciu o rozważania na temat diaspor jako kulturowych wspólnot tworzonych przez procesy negocjowania tożsamości, wewnętrznej heterogeniczności oraz własnych granic. Do ramy tej autorki włączają dodatkowo koncepcje ruchów społecznych, pokazując, w jaki sposób liderstwo oparte na łączeniu, dyskursywne struktury możliwości oraz emocje umożliwiły transnarodową mobilizację wokół \#CzarnegoProtestu. Opierając się na wywiadach jakościowych z organizatorkami protestów, autorki wskazuja, że \#CzarnyProtest zainicjowal powstanie feministycznej, transnarodowej diaspory wewnątrz społeczności migranckich.

SŁOWA KLUCZOWE: transnarodowa diaspora, feministyczna mobilizacja, mobilizacja stymulowana medialnie, \#CzarnyProtest 